\title{
The Legal Analysis of Notary/PPAT Who Takes a Leave but Keep Make Legal Deed
}

\author{
Dinnie Angraeni \\ Masters of Notary Study of Universitas Hasanuddin \\ Jl. Perintis Kemerdekaan KM.10, Tamalanrea, Makassar, Sulawesi Selatan, 90245 \\ dnny.angraeni@yahoo.com \\ Nurfaidah Said \\ Department of Civilization, Faculty of Law, Universitas Hasanuddin \\ Jl. Perintis Kemerdekaan KM.10, Tamalanrea, Makassar, Sulawesi Selatan, 90245 \\ Hasbir Paserangi \\ Department of Community Law and Development, Faculty of Law, Universitas \\ Hasanuddin \\ Jl. Perintis Kemerdekaan KM.10, Tamalanrea, Makassar, Sulawesi Selatan, 90245 \\ Muhammad Ilham Arisaputra \\ Department of Civilization, Faculty of Law, Universitas Hasanuddin \\ Jl. Perintis Kemerdekaan KM.10, Tamalanrea, Makassar, Sulawesi Selatan, 90245 \\ ilhamarisaputra@gmail.com
}

\begin{abstract}
Notary and Land Registrar (i.e. Pejabat Pembuat Akta Tanah [PPAT]) are general officials authorized to make authentic deeds. If someone is serving as a notary as well as being able to carry out his position, then he must be replaced by someone else temporarily. During the leave period, the land certificate they make is not authentic. The certificate sourced from and made by Notary or PPAT Deed is an authentic one that has perfect verification power. Therefore, every Notary or PPAT in carrying out the position should always be careful and aware of the consequences that can be caused on each deed he makes.
\end{abstract}

Keywords: Land Deed; Notary; Land Registrar (PPAT)

\section{A. INTRODUCTION}

The regulations related to the post of Notaries in Act No. 2 of 2014 on the Amendment Act No. 30 of 2004 concerning Notary (abbreviated as UUJN) explains that a Notary while carrying out his respective duties as General official, must abide to the Notary Law, adhere to the Professional Code of Ethics, must be accountable to the communities, the Notaries Association and the state. Both the law and the Notary Code of Ethics want Notary to carry out their duties properly. With this association, Notaries who ignore nobleness and dignity of his position, will get reprimand letter or dismissal sanction from his post as Notary, even can be extended to moral sanction (Fuady, 2005). 
Article 1 of the UUJN determines that "a Notary is a public official authorized to make authentic deeds and other authorities as intended in this law or under other laws". The most important and basic authority possessed by a notary is the making of authentic facts. The authenticity of the act made by a notary according to Article 1868 of the Civil Code is on the basis of reflecting the will of the parties as outlined in the form of a deed. Therefore, the authenticity of this deed does not need to be doubted (Ridodi, 2017).

In carrying out the position as Notary, he/she also concurrently acting as Land Deed Registrar (abbreviated as PPAT). This is done to increase the working range of the notary, that is because PPAT also has its own authority stipulated in Government Regulation Number 37 of 1998 concerning Position Regulations of Land Deed Registrar as amended by Government Regulation Number 24 of 2016 concerning Amendment of Government Regulation Number 37 of 1998 concerning Position Regulations of Land Deed Making Registrar (abbreviated as PP concerning PPAT). Article 1 of the PP concerning PPAT stipulates that PPAT is a general official who authorizes to make authentic deeds regarding certain legal actions of land rights or Property Rights to a Unit of Flats. Then, Article 2 PP concerning PPAT stipulates that: 1. PPAT has the principal duty to carry out part of land registration activities by making a deed as proof of certain legal actions regarding land rights or Ownership Rights over Flats, which will become the basis for registration of changes to land registration data due to legal actions.

2. Legal actions as referred to in paragraph (1) are as follows:
a. trade;
b. exchange;
c. grant;
d. investmen (inbreng);
e. sharing of the rights;
f. granting of Building Use Rights/Right to Use for Ownership Land;
g. granting of mortgage rights;
h. granting authorization to imposes a mortgage rights

Furthermore, in Article 3 of the PP concerning PPAT, the authority of the PPAT is stated, namely making an authentic deed concerning all legal acts as referred to in Article 2 paragraph (2) concerning land rights and Property Rights to the Unit of Flats which are located within the working area. Whereas the special PPAT is only authorized to make deeds regarding legal acts specifically referred to in its appointment. The Land Deed Maker official was appointed by the government, in this case by the National Land Agency of the Republic of Indonesia with certain duties and authority in serving the needs of the community for the transfer of land rights, land rights, and the provision of power of attorney as stipulated in applicable laws and regulations. 
A person who serves as a Notary is not prohibited from serving as a PPAT, except concurrently as a PPAT outside the area of his Notary's position. This is expressly regulated in Article 17 paragraph (1) letter g UUJN. For this reason, the notary may hold a position as PPAT as long as he is in the same working area.

Notaries and PPATs have their respective leave rights. The provisions regarding notary leave are regulated in Article 25 to Article 32 of the UUJN. If a notary takes leave, he is obliged to appoint a Substitute Notary as stipulated in Article 25 paragraph (3) of the UUJN. Likewise, with PPAT where in Article 31 PP concerning PPAT is regulated regarding PPAT leave rights.

In 2006 the Regulation of the Head of the National Land Agency of the Republic of Indonesia Number 1 of 2006 was issued concerning the Provisions on the Implementation of Government Regulation Number 37 of 1998 concerning Officials of Land Deed Making (abbreviated as Perkaban No. 1 of 2006) and to date Perkaban No. 1 of 2006 has never been replaced while Government Regulation No. 37 of 1998 concerning Officials of Land Deed Makers has been amended. PP regarding PPAT gives authority to PPAT who will leave to appoint Substitute PPAT, while Perkaban No. 1 of 2006 regulates more specifically in Article 38 paragraph (3) that "In the event that the PPAT carries out leave, then the application for leave as referred to in paragraph (1) may be accompanied by a proposal to appoint a replacement PPAT, except in that work area there has been another PPAT appointed by the Head of the Agency ". Article 38 paragraph (3) Perkaban No. 1 of 2006 shows that the replacement PPAT can only be proposed by PPAT who will leave if there is no other PPAT appointed by the Head of the National Land Agency in the PPAT working area.

The aforementioned provisions result if a PPAT person takes a leave while in his working area, there must be another PPAT appointed by the Head of the National Land Agency. So, he only applies for leave and does not submit a substitute. Even the practice in the field of someone who serves as PPAT does not submit leave even though as a Notary he goes on leave.

There is a phenomenon in Makassar where a Notary who also doubles as PPAT filed for leave for 21 (twenty one) days from November 16 until November 30, 2016 in which the Notary/PPAT the appointed Notary B as Substitute Notary has been approved by the Makassar City Regional Supervisory Board with the issuance of the Decree of the Supervisory Board of the City of Notary Makassar Number: 03/KETCUTI.MPDN.MKS/XI/2016 concerning Notary Leave which means Notary B as a Substitute Notary working to replace Notary A leave. However, Notary A only submit the leave of absence for the post of Notaryonly - his, whereas in Article 30 paragraph (1) Regulation of PPAT determine PPAT is prohibited to leave office more than six (6) working days successively except in order to take leave. Therefore, the position of Notary A as PPAT should still continue, unless he also submits leave for his PPAT position. But the fact is Notary A does not apply for leave for his PPAT position, so that 
it can be assumed that the post PPAT Notary A has prevailed. In possessing the duty, PPAT published deed of sale \& purchase while still in the period of leave.

\section{B. DISCUSSION AND ANALYSIS}

\section{Authority and Deed of Land Deed Maker Officer}

Article 3 of Government Regulation Number 37 of 1998 stated that to carry out the main duties, the PPAT has the authority to make authentic deeds related to all legal acts, such as land rights, property rights and/or unit flats located in the work area. While the Special Acting Official of PPAT is only authorized to make a deed concerning legal acts when appointed.

Muhammad Yamin stated that in organizing land ownership registration, the exixtence of PPAT is necessary. The deeds published and signed by PPAT can be used as a strong basis for registering the transfer of rights and imposition of rights. Based on Government Regulation Number 24 of 1997, transfer of land and objects on it are carried out by PPAT deed. The transfer of land from the owner to the recipient is accompanied by a juridical submission, and the submission must fulfill the formalities of the law, including fulfillment of requirements; carried out through prescribed procedures; use documents; and all made and signed before PPAT (Muhammad, 1994).

The PPAT deed is made as a proof that serves to ascertain legal event in order to avoid a dispute. Therefore, the making of deeds must be such that the art does not contain unclear matters so as not to cause disputes in the future. Article 4 paragraph (1) of Government Regulation Number 37 of 1998 affirms that PPAT is only authorized to make deeds regarding land rights or Ownership Rights over Flats which are located in its working area. Exceptions to Article 4 paragraph (1) are specified in paragraph (2), namely for exchange certificates, investment deeds in companies (inbreng) and joint rights deeds regarding several land rights and Property Rights to Flats which are not all located in a work area of PPAT, can be made by PPAT whose working area includes one part of the land or apartment units whose rights are the object of legal action. Furthermore, it is stated in Article 21 regarding PPAT that:

a. The PPAT deed is made in the form stipulated by the Minister.

b. All types of PPAT deeds are given one serial number that recurs at the beginning of the calendar year.

c. The PPAT deed is made in the original form in 2 (two) sheets, namely:

1) the first sheet of 1 (one) duplicate is kept by the PPAT concerned, and

2) the second sheet as many as 1 (one) duplicate or more according to the number of land rights or Ownership Rights over the Flat Unit which is the object of legal actions in the deed, which is submitted to the Office of Land for registration purposes, or in the case of the deed concerning the granting of power of attorney Mortgage Rights, submitted to the power of attorney for the basis of the making of the 
Deed of Giving Rights, and to the parties concerned can be given a copy.

Then Article 22 PP concerning PPAT stipulates that "the PPAT Deed must be read/explained its contents to the parties in the presence of at least 2 (two) witnesses before being signed immediately and by the parties, witnesses and PPAT". Whereas Article 23 PP concerning PPAT stipulates that:

a. PPAT is prohibited from making a deed, if the PPAT itself, his husband or wife, his family is blood or fine, in a straight line without limiting the degree and in the side line to the second degree, becomes a party in the legal action concerned, either by acting alone or through power, or become the power of another party.

b. In the Sub district area there is only a PPAT, namely PPAT Provisional and in the village area whose Head of Village is designated as Provisional PPAT, the Deputy Sub-District Head or Village Secretary can make a request for the parties as referred to in paragraph (1) ahead of the PPAT while concerned.

Article 3 Perkaban Number 1 Year 2006 stipulates the authority of PPAT, namely making land deeds which are authentic deeds concerning all legal actions as referred to in Article 2 paragraph (2) concerning land rights and ownership rights to apartment units located in their working area. Then the Provisional PPAT has the authority to make land deeds which are authentic deeds concerning all legal actions as referred to in Article 2 paragraph (2) concerning land rights and ownership rights to apartment units with work areas in their working area. Whereas the special PPAT is only authorized to make deeds regarding legal actions specifically mentioned in their appointments.

\section{The Legal Status of Certificate Made by PPAT on the Leave Period of Notary Position}

Article 1 point 1 of the UUJN states that a Notary is a public official authorized to make other authentic and authoritative deeds as referred to this law or under other laws. This Article explains that a Notary is a public official authorized to make authentic deeds regarding an act, agreement and stipulation required by a general regulation or desired to be stated in an authentic deed, guarantee the date, keep the deed and provide a grosse, copy and the quotation, all as long as the deed was made by a general regulation not also assigned or excluded to officials or other people. A notary is obliged to keep everything entrusted to him and may not hand over copies of deeds to unauthorized persons (Lumban Tobing, 1992).

Then Article 1 number 1 PP concerning PPAT defines PPAT as a general official who is authorized to make authentic deeds regarding certain legal actions regarding land rights or Ownership Rights over Flats Unit. This provision shows that a Notary Position and PPAT Position is a public position which is authorized by legislation to 
make authentic deeds. If a Notary is an official authorized to make authentic deeds in general, then PPAT is a public official authorized to make deeds in the land sector.

Notaries and PPATs have an important role in helping people who want to legitimize legal actions and legal relationships that they make, namely making authentic deeds that have perfect proof power. The position of Notary and PPAT is a position of trust so that a Notary and PPAT must have good behavior, both in carrying out their positions and in their social life.

Notaries and PPAT are not only authorized officials according to UUJN and PP regarding PPAT, but also on the other hand Notary and PPAT have life as human beings so that a notary will certainly experience certain obstacles that are human in carrying out their duties and authorities such as illness, doing spiritual activities, and so forth. For this reason, in carrying out his nature as an ordinary human being the notary is also entitled to temporarily not carry out his duties as a public official. For this reason, UUJN and PP concerning PPAT give the right to take leave for Notaries and PPAT. In the context of this leave, Notary and PPAT allowed to designate Substitute Notary and PPAT to perform temporary duties and position.

In UUJN, the rules regarding Notary leave are regulated in Article 25 to Article 32. Article 25 UUJN determines that the Notary has the right to leave. The right to leave can be taken after the Notary has run the office for 2 (two) years and during the leave, the Notary must appoint a subtitute Notary. Leave rights for Notary can be taken every year or at the same time for several years, a maximum of 5 years in a row (in the sense of one time leave request and including extension) and accumulated Notary leave is no more than 12 (twelve) years. This is regulated in Article 26 UUJN. In carrying out the decree, the Notary must submit a Notary Protocol to the Substitute Notary and the Substitute Notary return the Notary Protocol to the Notary after the leave ends. The receipt of the Notary Protocol is made by making minutes and submitted to the Regional Supervisory Board.

Regarding PPAT leave, this is stipulated in the PP concerning PPAT and Perkaban No. 1 of 2006. In Article 30 of the PP concerning PPAT, it is stipulated that PPAT is prohibited from leaving its office for more than 6 (six) consecutive working days except for the purpose of taking leave. Leave requests is submitted and written to the authorities, namely:

a. Head of Land Office of the local Regency/Municipality for requesting the leave less than 3 (three) months;

b. Head of Regional Office of the National Land Agency of the Province for requesting the leave more than 3 (three) months but less than 6 (six) months;

c. The Minister for requesting the leave more than 6 (six) months.

As long as the PPAT is on leave, the duties and authority of the PPAT can be carried out by a substitute as requested by PPAT. The substitute is proposed by the 
relevant PPAT and appointed by an official who authorized to determine leave agreement and taken an oath by the Head of Local Land Office.

In the case of PPAT who takes a leave, the request for leave can be accompanied with a proposal to appoint the substitute, except there is already another PPAT appointed by the Head of the Agency in the PPAT's work area. This can be interpreted that in a condition where there are more than one PPAT in the working area, then there is no need for a replacement if one of the PPAT takes a leave. However, in fact there are those who, in such condition, still propose a replacement for PPAT and approved. Another case, there are also PPATs who leave but do not appoint a replacement, so there is no transfer of the PPAT protocol. Additionally, in fact, many PPAT officials think that if they want to take time off, there is no need for PPAT to appoint a replacement when the leave is proposed.

That conditions cause uncertainty because the protocol of PPAT must always be in active. This is explained in Governement Regulation Article 30 paragraph (1) concerning PPAT which is regulated that PPAT is prohibited for leaving the office more than 6 (six) consecutive working days except the official means to take a leave. This means that the PPAT protocol must always be running and the leave is not blocking the continuity of the PPAT's Protocol.

In Perkaban No. 1 of 2006 Article 38 paragraph (3) in fact made several PPATs who would take leave, in the end did not apply for leave. A person who serves as a Notary as well as a PPAT usually only submits the Notary leave, while the PPAT position is not submitted for leave. For example, the case occurred in Makassar City where a Notary/PPAT applied the leave for 21 days, but the leave submitted was only for the position of Notary, not the PPAT position. The application for Notary leave is submitted as well as the appointment of substitute Notary. This happens because it is related to the Protocol or the Book of Deed Lists. A PPAT usually do not want the Book of Deed Lists is left to someone else, especially to the one he/she does not recognize.

It is for certain that this condition contradicts with the Government Regulation Article 30 paragraph (1) of PPAT which prohibits a PPAT from leaving its office more than 6 (six) consecutive working days except for the purpose of taking leave. If they do that, the PPAT will be sanctioned in accordance with the applicable laws and regulations.

Notaries and PPATs are public officials who have their own characteristics, Notaries and PPAT carry out part of the state's authority in making deeds. According to the authors, Notaries and PPAT are positions that complement each other with their respective authorities. The question that always arises is what if a person serves as a Notary as well as a PPAT and he/she proposes the leaves for his/her Notary position, is it the PPAT position will be automatically on leave. Notary Position and PPAT Position can be held by 1 (one) person. For that reason, if the person concerned is in a condition unable to carry out the duties, then the official has the right to take 
leave. The filing of Notary leaves and PPAT is submitted to the authorized officials appointed by UUJN and Governemet Regulation of PPAT. Therefore, if the relevant person submits the leave, the submission is not only for 1 (one) position, but for 2 (two) positions at once. Howefer, if the leave submission is only for 1 (one) position, it means that the other position is considered still in active. This means that the person concerned must continue to carry out his position in a real way because UUJN and Governemet Regulation of PPAT prohibit the Notary/PPAT from leaving his work area for no apparent reason.

Based on the explanation above, the problem that occured in Makassar is consirered as a vioalation of Governemet Regulation of PPAT in Article 30. The detailed problem is that only the position of Notary is submitted for a leave and not the postion of PPAT. The reason of the leaving is performing umrah in Mecca. If it is the reason for the Notary's leave, then of course the PPAT position will not work either because the person concerned will leave the PPAT work area for more than 6 (six) consecutive days. In this context, the person concerned should apply for leave for his Notary position as well as his PPAT position because it is illogical where the Notary Position is inactive (due to leave) and in another hand the PPAT position is still active (not on leave).

Generaly, the Notary and PPAT positions are public positions that are not the same as other positions. The office of Notary and PPAT positions are attached to those who meet certain qualifications. In addition, the position of Notary and PPAT has its own protocol which will forever remain attached. Although during the implementation of his/her position is acted by the appointed substitute official of Notary/PPAT because of his/her leaving approved-proposal, the responsibility for the Notary Protocol/Book List of the PPAT Deed will continue to be carried out by the Notary/PPAT as long as he is still alive. For this reason, the position of Notary/PPAT cannot be delegated because the Notary/PPAT will take account for all the contents of the Notary protocol as long as he/she still alive, even though there are products made by the Substitute Notary/Substitute PPAT (Waldany, 2018).

The Substitute Notary/Substitute PPAT will not exist without beginning with a Notary/PPAT leave or other obstacles that cause the Notary/PPAT unable to carry out his/her position. This also becomes the difference between the position of Notary/PPAT with the State Administrative position where State Administrative positions can delegate the authority existed from the beginning. Whereas the Substitute Notary/Substitute PPAT will unable to carry out the authorities if not referred by the Notary/PPAT who. On this basis, the authority exercised by the Substitute Notary/Substitute PPAT is not the delegated or mandated authority, but an attribution authority that ordered directly by law and cannot be carried out by other organs (Waldany, 2018). 
Looking back on Article 38 paragraph (3) of Perkaban No. 1 of 2006, this provision is supplemented by the provisions of Article 38 paragraph (6) which stipulates that "Before taking a leave, the PPAT is obliged to close the Book of Deed Lists, reporting to the Head of Local Land Office and unnecessary to make monthly reports". This provision affirms that if a PPAT submits a leave, then it is not permitted by statutory provisions to appoint a Substitute PPAT if there is already another PPAT in the working area who appointed by the Head of the National Land Agency Office. If the PPAT submits leave and the request for restitution is approved by the competent authority in accordance with Article 38 paragraph (1) Perkaban No. 1 of 2006, he must close the List of Deeds and report to the Head of the Local Land Office. During the leave, the PPAT is deemed not to carry out his PPAT work and is not required to make a monthly report.

The above problematic case in Makassar showed that the person has two positions at once: Notary and PPAT. Accordingly, when the official who has two positions intents to take a leave, it is obliged to submitting the leave for both positions. In simple terms, it is irrational to act the duties as PPAT while he/she on his/her leaving of the duties as Notary. This condition will certainly have an impact on the deed he/she made. The deed made by this official as PPAT while on leave as Notary considered as an informal deed (i.e di bawah tangan). This is based on the position of PPAT which actually gets a permanent obstacle to carry out the duties as PPAT but does not submit the leave. It results in violation of the provisions of Governement Regulation of PPAT in Article 30 paragraph (1). For that purpose, the PPAT office of the concerned should be deemed inactive. Thus, the concerned person cannot carry out his position until the end of the leave as Notary. If the leave period as Notary is unfinished and the person makes a deed as PPAT, then the author argues that the person is only an ordinary clerk without formal position and authority.

In Makassar, the ' $A$ ' as an official of Notary and PPAT continued to run the PPAT's duties in the middle of the leave as Notary. In this condition, the ' $A$ ' issued a Deed of Sale and Purchase that should not be made because the position as PPAT is constrained by the leave as Notary. According to the author, the position of the PPAT that issued the deed while in fact he had a permanent obstacle to carrying out the duties, then the deed made in that condition is a deed created by an ordinary clerk who just made the concept of the agreement to both parties. Even though the ' $A$ ' acted as PPAT position, in reality the ' $\mathrm{A}$ ' could not carry out the duties because the person was still counted unable to act due to performing Umrah. Because the position of the Notary is still counted on leave, then of course it has an impact on the position of PPAT which should be calculated on leave as well. Then from that, the deed made by the concerned official according to the author is unofficial deed.

As defined, Authentic Deed is a deed made by an authorized official. This understanding shows that an authentic deed is a deed made by an active official who is authorized for it. If the Notary/PPAT takes leave, then he/she is not permitted to 
make a deed. If he/she makes a deed, then the deed he/she made is not an authentic deed.

\section{Legal Implications Against Deed Made by PPAT That Should Have Calculated Leave Along with The Leave Period of the Notary Position}

The deed made by a Notary and PPAT is an authentic deed that proves a legal act committed between the parties, so that the authentic deed made by or before a Notary/PPAT is able to guarantee the certainty, order and legal protection. According to Philipus M. Hadjon (Adjie, 2008) the authentic deed must fulfill the conditions (1) This deed must be made "by" or "before" a public official; and (2) Deed made in the form determined by law.

A deed of authority is a binding evidence in the sense that something written in the deed must be considered correct and trust-worthy by the judge. The authentic deed also provides a perfect proof because it does not require the addition of other evidence. An authentic certificate can prove legally and strongly the existence of a legal relationship between the parties that makes it, so that legal certainty is created.

Notary and PPAT are responsible for the deed they made. This provision for example is regulated in Article 65 of the UUJN which stipulates that, "Notaries, Substitute Notaries, and Temporary Notary Officials are responsible for any Deed made even though the Notary Protocol has been submitted or transferred to the depositary party". Such provisions are not contained in the Government Regulation on PPAT, but the PPAT's responsibility for the making the deed is attached to the position. Notaries and PPAT are general officials who are given their respective authority as stipulated in UUJN and Government Regulation on PPAT. Each authorized official has responsibility for implementing that authority. Thus, the Notary and PPAT, on the basis of the authority given by the laws and regulations, bear big responsibility.

According to Kranenburg and Vegtig there are two theories underlying the accountability of officials (Ridwan, 2010):

a. The theory of fautes personalles, that is the theory which states that losses of the third parties are charged to officials who, because of their actions, have caused losses. In this theory the burden of responsibility is directed at humans as individuals.

b. The theory of fautes de services, that is the theory which states that losses of third parties are borne by agencies of the relevant officials. According to this theory responsibility is imposed on the office. In its application, the losses incurred are also adjusted whether the mistakes made are serious mistakes or minor mistakes, where the weight and severity of a mistake have implications for the responsibility that must be borne.

Based on the explanation above, the Notary and PPAT are clearly fully responsible for the deeds they make. Notary and PPAT positions as public officials cause both of them to be charged with responsibility for the legal products they 
produce. What is stated from the beginning of the deed to the end of the deed Notary/PPAT is an expression that reflects the true condition at the time of making the deed. Therefore, the Notary and PPAT are fully responsible for the contents of the deed they made. The responsibility of the Notary and the PPAT for the deed is a form of personal responsibility, not only in their position, but also attached to their personality.

Deed is a proof of an agreement, where the contents of the deed are the implementation of what the parties want. However, if the agreement is broken, the it has two legal implications which are: (1) can be cancelled and (2) null and void by law. This is related to the legal requirements of an agreement as specified in Article 1320 BW (Burgerlijk Wetboek voor Indonesie), which are: agreed, competent, certain matters, and the legal reasons. According to Kartini (Muljadi \& Widjaja, 2008) the four elements, in the development of the doctrine of law, are classified into 2 (two) main elements concerning the subject (party) which enter into an agreement (subjective element) and 2 (two) other principal elements which is directly related to the object of agreement (objective element). The subjective element includes the element of agreement that is freely agreed upon by the parties and the skills of the parties implementing the agreement. Whereas the objective element includes the existence of the issue which is the object of agreement and causality of the object in the form of an achievement agreed upon to be carried out and it must be something that is not prohibited or permitted according to the law.

If an agreement does not meet the subjective requirements, then the agreement can be canceled. In fact, the parties can request the cancellation of the agreement to the judge and as long as the agreement is not requested for cancellation, then the agreement is still recognized as a legal agreement. If the agreement does not meet the objective requirements for certain matters, then the agreement has never existed since the beginning. Whereas if the objective aspect of the halal cause (permitted by law) is not fulfilled, it can result in the birth of natural engagement, meaning that the agreement cannot be enforced (Widjaja, 2006).

The provisions of Article $1320 \mathrm{BW}$ are cumulative, meaning that each agreement must fulfill all four requirements together. If one condition in the provisions of Article $1320 \mathrm{BW}$ is not fulfilled, it will cause the agreement to become a legal defect that can be questioned in the sense that it can be canceled or can be canceled by a third party concerned.

The defect of the Notary/PPAT deed can cause a cancellation of a deed that has been made and cause the legal act to be invalid or has no legal consequences. The quality of an authentic deed made by a Notary and PPAT is divided into 2 (two) types, namely:

a. Formal defect. The formal defect that the author means are the deviations of formal requirements in making a deed. The legal implication of this 
formal defect is that the deed can be requested for cancellation by parties who feel disadvantaged by its issuance.

b. Material defect. Material defects that the author means are the deviations of material requirements in making a deed. The legal implication of this material defect is that the deed was null and void so that the deed was never considered.

Regarding the issue discussed above, according to the author, the deed made by the PPAT who should takes a leave is a formal defect deed. This formal defect means that the deed is made by the unauthorized PPAT. As explained by Peter E. Latumeten that indicator of unauthorized act is people who because of their work or position by law are prohibited or unlicensed to carry out certain legal actions. In this context, the PPAT concerned should be in the period of leave because of permanent obstacle to exercise the authority that is performing umrah. The PPAT position is actually cannot carrying out the duties and has the authorities because not in the working area as it stated by Government Regulation on PPAT that PPAT's official prohibited from leaving his/her working area for 6 working days in a row. Additionally, Article 1869 BW has also determined that a deed made by concerned PPAT loses its authenticity either because the unauthorized position, incapable of the relevant public official, or because of a defect in its form so that it can be degraded and it just privately made deed eventhough signed by the parties.

Notary/PPAT as a general official of deeds has moral responsibility for the deed he/she made because he/she trusted to compile and formulate the wishes of the parties in the deed. The notary/PPAT must be responsible for the deeds made by and or before him/her with the warning that the mistakes made by the Notary/PPAT in making the deed, he/she required to pay fines or all costs incurred, compensation, and interest for violations he/she has committed.

\section{CONCLUSION}

The legal status of the deed made by the PPAT which should have taken the leave at same time as the notary leave is privately made deed. Logically, someone who serves as a Notary and PPAT at the same time, if he gets a permanent obstacle to carry out his duties and authorities, then he must take leave because UUJN and Government Regulation on PPAT prohibit Notaries and PPAT from leaving their work area 6 days and 7 days in a row for non permissible reason. If the official requests a leave for his position as Notary, then his position as PPAT must also proposed for a leve. In such conditions, the PPAT should be counted on leave. The deed he made at that time is not deed made by PPAT but only as a regular clerk who helps others to make deeds. Thus, the produced-deed is a privately made deed and not an authentic deed because the Notary/PPAT who is on leave is not permitted by UUJN or Gevernment Regulation of PPAT to make a deed. 
The legal implications of the deed made by the PPAT which should be calculated at the same time as the notary leave are that the deed can be requested for cancellation to the court. The deed made by the PPAT which is supposed to be on leave contains formal defect. The formal defect in is the absence of the authority of the PPAT that made the deed because in this context the PPAT concerned gets a permanent obstacle to carrying out the duties and authorities.

\section{REFERENCES}

Adjie, H. (2008). Sanksi Perdata dan Adminitratif Terhadap Notaris Sebagai Pejabat Publik. Bandung: Refika Aditama.

Fuady, M. (2005). Etika Profesi Hukum Bagi Hakim, Jaksa, Advokat Notaris, Kurator dan Pengurus-Pengurus Profesi Mulia. Bandung: PT. Citra Aditya Bakti.

Lumban Tobing, G. (1992). Peraturan Jabatan Notaris. Jakarta: Erlangga.

Muhammad, A. K. (1994). Hukum Harta Kekayaan. Bandung: Citra Aditya Bhakti.

Muljadi, K., \& Widjaja, G. (2008). Perikatan Yang Lahir Dari Perjanjian. Jakarta: Raja Grafindo Persada.

Ridodi, M. A. (2017). Batasan Kewenangan Notaris d an PPAT Dalam Membuat Akta Yang Berkaitan Dengan Tanah. Lambung Mangkurat Law Journal, 2(1), 119128.

Ridwan. (2010). Hukum Administrasi Negara. Jakarta: Rajawali Press.

Waldany, A. R. A. (2018). Kewenangan Notaris Yang Cuti Untuk Mengangkat Notaris Pengganti Sebagai Pemegang Protokol. Universitas Hasanuddin.

Widjaja, G. (2006). Penerbitan Obligasi Dan Peran Serta Tanggung Jawab Wali Amanat Dalam Pasar Modal. Jakarta: Kencana. 